\title{
Bioactive compounds in different acerola fruit cultivares
}

\section{Compostos bioativos em diferentes cultivares de acerola}

\author{
Flávia Aparecida de Carvalho Mariano-Nasserr'; Maurício Dominguez Nasser; \\ Karina Aparecida Furlaneto ${ }^{3 *}$; Juliana Arruda Ramos ${ }^{4}$; Rogério Lopes Vieites ${ }^{5}$; \\ Maximiliano Kawahata Pagliarini ${ }^{6}$
}

\begin{abstract}
The increased consumption of acerola in Brazil was triggered because it is considered as a functional food mainly for its high ascorbic acid content, but the fruit also has high nutritional value, high levels of phenolic compounds, total antioxidant activity, anthocyanins and carotenoids in its composition. The objective was to evaluate the chemical, physical-chemical and antioxidant activity of eight varieties of acerola tree. The acerolas used in the research were the harvest 2015, 8 varieties: BRS 235 - Apodi, Mirandópolis, Waldy - CATI 30, BRS 238 - Frutacor, Okinawa, BRS 236 - Cereja, Olivier and BRS 237 - Roxinha, from the Active Bank Germplasm APTA Regional Alta Paulista in Adamantina - SP. Avaluated the following attributes: $\mathrm{pH}$, titratable acidity, soluble solids, reducing sugar, instrumental color, ascorbic acid, total phenolics, flavonoids and antioxidant activity. The design was completely randomized, 8 varieties and 3 replications of 20 fruits each. Acerola fruit of the analyzed varieties prove to be good sources of phenolic compounds and antioxidant activity, ensuring its excellent nutritional quality relative to combat free radicals. The variety BRS 236 - Cereja presents higher ascorbic acid content, antioxidant activity and phenolic compounds, and the lowest value for flavonoid, which was higher than the other cultivars, especially Olivier and Waldy CATI-30.
\end{abstract}

Key words: Antioxidants. Malpighia emarginata Sessé \& Mociño ex DC. Polyphenols. Secondary metabolism.

\section{Resumo}

O aumento do consumo de acerola no Brasil foi desencadeado por ser considerada como alimento funcional principalmente por seus altos teores de ácido ascórbico, mas o fruto também apresenta alto valor nutritivo, elevado teores de compostos fenólicos, atividade antioxidante total, antocianinas e carotenoides em sua composição. O objetivo do trabalho foi avaliar as características químicas, físicoquímicas e atividade antioxidante de oito cultivares de aceroleira. As acerolas utilizadas na pesquisa foram da safra 2015, de 8 cultivares: BRS 235 - Apodi, Mirandópolis, Waldy - CATI 30, BRS 238 - Frutacor, Okinawa, BRS 236 - Cereja, Olivier e BRS 237 - Roxinha, proveniente do Banco Ativo

1 Eng $^{\mathrm{a}}$ Agra ${ }^{\mathrm{a}}$, Pós-Doutoranda em Horticultura, Faculdade de Ciências Agronômicas, UNESP, Botucat, SP, Brasil. E-mail:flaviamariano1@hotmail.com

2 Eng $^{\mathrm{o}}$ Agr $^{\mathrm{o}}$, Pesquisador Científico da APTA Regional Alta Paulista, Adamantina, SP; Discente de Doutorado em Horticultura, UNESP, Botucatu, SP, Brasil. E-mail:mdnasser@apta.sp.gov.br

3 Eng $^{\text {a }}$ Agr $^{\text {a }}$, Discente de Doutorado em Energia na Agricultura, UNESP, Botucatu, SP, Brasil. E-mail: karina_furlaneto@globo. com

4 Nutricionista, Discente de Doutorado em Energia na Agricultura, UNESP, Botucatu, SP, Brasil. E-mail: ju.a.ramos@globo.com

5 Prof. Titular, UNESP, Botucatu, SP, Brasil. E-mail:vieites@fca.unesp.br

6 Eng $^{\circ}$ Agr $^{\circ}$, Dr. em Agronomia, Técnico em Agropecuária, Universidade Federal da Grande Dourados, Fazenda Experimental de Ciências Agrárias, Dourados, MS, Brasil. E-mail: mpagliarini@ufgd.edu.br

* Author for correspondence

Received: Sept. 01, 2016 Approved: May 12, 2017 
de Germoplasma da APTA Regional Alta Paulista em Adamantina - SP. Avaliaram-se os seguintes atributos: $\mathrm{pH}$, acidez titulável, sólidos solúveis, açúcar redutor, cor instrumental, ácido ascórbico, compostos fenólicos totais, atividade antioxidante e flavonoides. O delineamento utilizado foi o inteiramente casualizado (DIC), com 8 cultivares e 3 repetições com 20 frutos cada. Frutos de acerola das cultivares analisadas mostram-se boas fontes de compostos fenólicos totais e atividade antioxidante, garantindo sua excelente qualidade nutricional em relação ao combate de radicais livres. A cultivar BRS 236 - Cereja apresenta maiores teores de ácido ascórbico, atividade antioxidante e compostos fenólicos totais, e o menor valor para flavonoides, que foi superior nas demais cultivares, com destaque para Olivier e Waldy CATI-30.

Palavras-chave: Antioxidantes. Malpighia emarginata Sessé \& Mociño ex DC. Metabolismo. Secundário polifenóis.

\section{Introduction}

It is not today, there is great concern about issues related to health. Thus, the demand for food with functional properties, in order to intake compounds with antioxidant potential, increased. These constituents combating free radicals and may prevent or retard oxidative damage to proteins, lipids and nucleic acids, decreasing aging, cardiovascular diseases risk and cancer due to free radicals inactivation in the body (ANDRADE et al., 2013; FREIRE et al., 2013; ROCHA et al., 2013; RUFINO et al., 2009).

Antioxidants such as ascorbic acid is not synthesized by the human body, being necessary to intake by diet (CHITARRA; CHITARRA, 2005). Therefore, the consumption of fruits emerges as an excellent source of natural antioxidants, being more effective and economical that diet (MELO et al., 2008).

The increase in acerola fruit consumption in Brazil was triggered due to being considered as a functional food mainly for its high ascorbic acid content (DE ROSSO; MERCADANTE, 2005; MACIEL et al., 2010; VENDRAMINI; TRUGO, 2000). The fruit also has high nutritional value (MERCALI et al., 2013), high phenolic compounds levels, in addition to high total antioxidant activity (MELO et al., 2008; RUFINO et al., 2009; VIEIRA et al., 2011) beyond anthocyanins and carotenoids (AGOSTINI-COSTA et al., 2003; LIMA et al., 2011; MUSSER et al., 2004).

However an adult human body requires 75-90 mg day ${ }^{-1}$ of ascorbic acid (AMAYA-FARFAN et al., 2001), this compound may easily be lost through oxidation in storage, due to elevated temperatures, low humidity and physical damage (LEE; KADER, 2000). In this sense, it is convenient to characterize other bioactive compounds present in these fruits like phenolic compounds.

These levels may have different concentrations and compositions due to intrinsic factors such as cultivar, variety, maturity stage; and extrinsic factors such as climate and soil conditions of production area (MELO et al., 2008).

There are few varieties of acerola trees planted in Brazil. Okinawa, Sertaneja and Flor Branca are present in Minas Gerais, Sergipe, Bahia and Pernambuco states and Olivier and Waldy - CATI 30 in São Paulo state (FURLANETO; NASSER, 2015; RITZINGER; RITZINGER, 2011).

Although the literature rely on numerous studies of bioactive characterization of acerola fruits, a few point out the cultivars used. Thus the objective of this study was to evaluate chemical, physicalchemical traits and antioxidant activity of eight cultivars of acerola fruit.

\section{Material and Methods}

Fruits used in the research were harvested in 2015 of eight cultivars: BRS 235 - Apodi, Mirandópolis, Waldy - CATI 30, BRS 238 - Frutacor, Okinawa, BRS 236 - Cereja, Olivier and BRS 237 - Roxinha, from the Germplasm Active Bank at APTA Regional 
Alta Paulista in Adamantina - SP, Brazil (21 ${ }^{\circ} 40^{`} \mathrm{~S}$, $51^{\circ} 08^{\prime} \mathrm{W}$ and $400 \mathrm{~m}$ of altitude).

According to Köppen, the climate is Cwa and classified as humid subtropical, with warm and rainy summers and dry and mild winters (HERRERA et al., 1997). The precipitation and average annual temperature is $1,300 \mathrm{~mm}$ and 22 to $23^{\circ} \mathrm{C}$, respectively, with $26^{\circ} \mathrm{C}$ at warmest month (Figure 1). The collection soil was classified as RedYellow Argisol, eutrophic, sandy/medium texture and undulating topography (EMBRAPA, 2006).

Figure 1. Maximum and minimum temperatures and precipitation for harvest period.

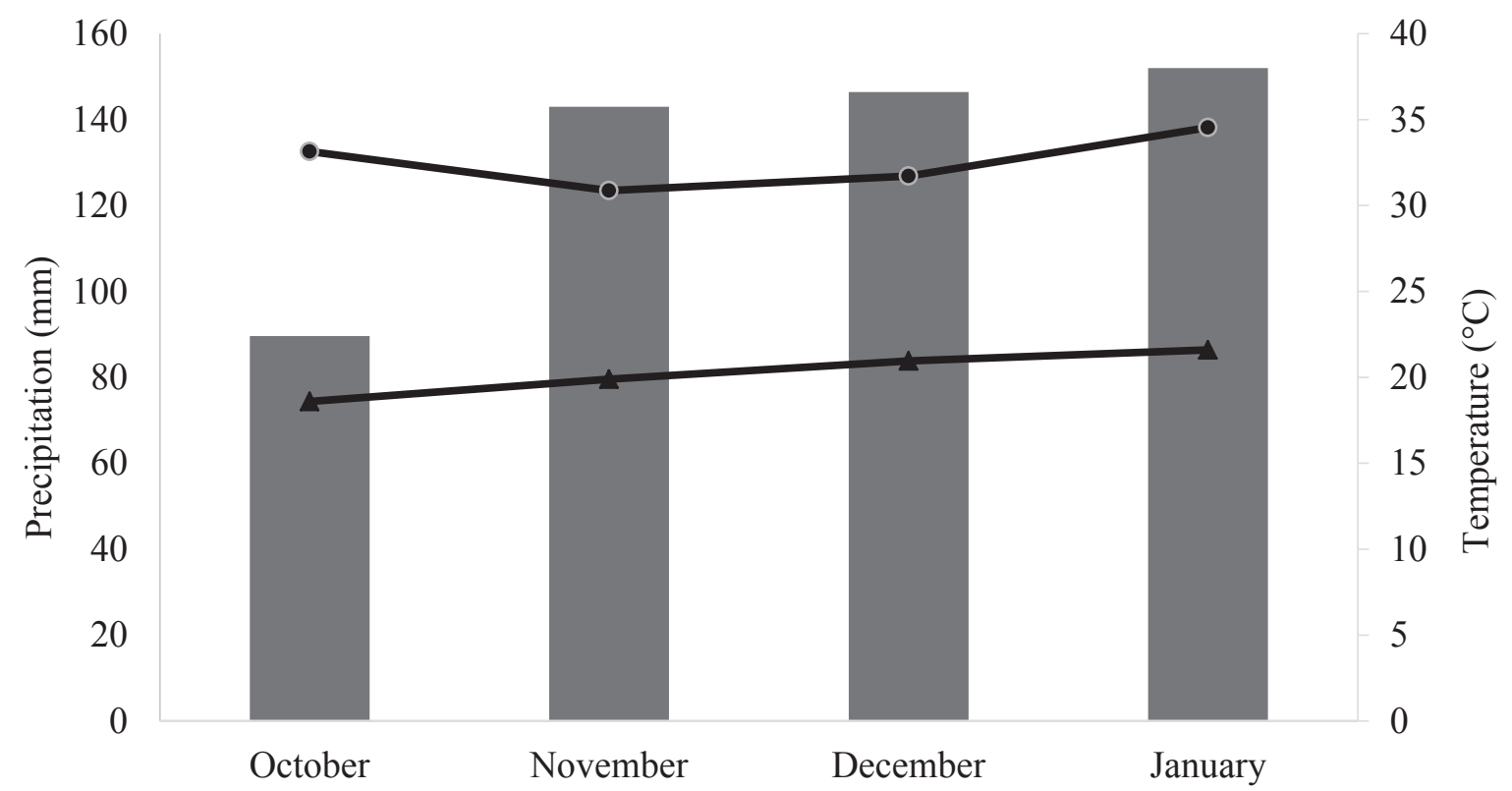

Harvest 2014/2015

Precipitation $\quad$-Minimum Temperature $\quad$ - Maximum Temperature

Source: APTA Regional da Alta Paulista weather station, Adamantina-SP, Brazil.

Two kilograms of ripe fruits (taken from eight plants of each cultivar) were harvested manually, in the morning and immediately frozen at $-20^{\circ} \mathrm{C}$. Later, fruits were packed into coolers and sent to Fruit and Vegetable Laboratory at Faculdade de Ciências Agronômicas in Universidade Estadual Paulista "Júlio de Mesquita Filho", Botucatu - SP, Brazil in order to perform physical-chemical and biochemical analysis.

The following traits were evaluated: $\mathrm{pH}$, tritratable acidity (expressed in $\mathrm{g}$ of malic acid 100 $\mathrm{g}^{-1}$ of pulp), soluble solids ( ${ }^{\circ}$ Brix) (INSTITUTO ADOLFO LUTZ, 1985) and reducing sugar (\% glucose) (NELSON, 1944; SOMOGY, 1945).

Instrumental colour was determined by evaluating two points in the peel and pulp of acerola fruit by Konica Minolta (Chroma meter CR 400) colorimeter to determine the values of Luminosity (L), Chroma and ${ }^{\circ}$ Hue. Where $\mathrm{L}$, expressed in percentage, indicates luminance values $(0 \%=$ black and $100 \%=$ white); the Hue angle is the value in degrees corresponding to colours three-dimensional 
diagram: $0^{\circ}$ (red), $90^{\circ}$ (yellow) and $270^{\circ}$ (blue). Hue angle ranges from 0 to $18^{\circ}$ for red-violet, 19 to $54^{\circ}$ for red, 55 to $90^{\circ}$ for orange, 91 to $126^{\circ}$ for yellow, 127 to $162^{\circ}$ for yellow-green, 163 to $198^{\circ}$ for green color, 199 to $234^{\circ}$ for blue-green, 235 to $270^{\circ}$ for blue, 271 to $306^{\circ}$ for blue-violet and 307 to $342^{\circ}$ for violet, 343 to $360^{\circ}$ for red-violet, making $360^{\circ}$. Chroma determines the intensity of colour ranging from zero (less intense colour) to 60 (intense colour) (MINOLTA, 1998).

Ascorbic acid content was determined by titration (Tillmans modified method), based on the reduction of 2-6-dichlorophenol-indophenol (DCFI) by ascorbic acid, following MAPA (Ministério da Agricultura Pecuária e Abastecimento) guidelines (BRASIL, 2005). The results were expressed in $\mathrm{mg}$ ascorbic acid $100 \mathrm{~g}^{-1}$ of pulp.

The extract was carried out using $0.1 \mathrm{~g}$ of acerola pulp and $5 \mathrm{~mL}$ of ethyl alcohol $(80 \%)$. The mixture was homogenized in Turrax and placed in ultrasonic bath for 15 minutes, then placed in centrifuge at 4 ${ }^{\circ} \mathrm{C}$ and $6000 \mathrm{rpm}$ for 20 minutes. Two successive extractions were made and supernatants from these extractions were combined and placed in amber bottle.

The content of phenolic compounds was determined by spectrophotometric method described by Singleton et al. (1999), where $0.1 \mathrm{~mL}$ of extract was mixed in $2.5 \mathrm{~mL}$ of Folin-Ciocalteu solution $(20 \%)$ and $2.0 \mathrm{~mL}$ of sodium carbonate $(4 \%)$ with dark incubation for 120 minutes.

The total antioxidant activity was assessed by DPPH (2,2-diphenyl-1-picrylhydrazyl), as suggested by Mensor et al. (2001). In a test tube $3 \mathrm{~mL}$ of ethyl alcohol, $0.5 \mathrm{~mL}$ of extract and 0.3 $\mathrm{mL}$ of DPPH were added with dark incubation for 45 minutes. The reading was performed in $517 \mathrm{\eta m}$ absorbance and the results were expressed in ability to radical scavenge in percentage.

Quantitation of flavonoid levels was performed according to Santos and Blatt (1998) and Awad et al. (2000) guidelines. In a sample of $0.2 \mathrm{~g}$ of acerola fruit was added $4 \mathrm{~mL}$ of acidified methanol and then taken into ultrasonic bath for 30 minutes, removed and added $1 \mathrm{~mL}$ of aluminium chloride solution $5 \%$ (weight/volume) in methanol. After that, put to incubate in the dark for 30 minutes and then centrifuged for 20 minutes at 6000 rpm. The supernatant was removed and read in a spectrophotometer at $425 \eta \mathrm{m}$ absorbance, the results were expressed in $\mathrm{mg}$ of quercetin $100 \mathrm{~g}^{-1}$ of sample.

The design was completely randomized, eight cultivars and three replications with 20 fruits each one. Biochemical analyses were performed in triplicate. Data were submitted to analysis of variance (ANOVA) and the means were compared by Tukey test with $\mathrm{p}<(0.05)$.

\section{Results and Discussion}

Among fruit quality traits (Table 1), soluble solids content of acerola cultivars ranged from $6.6^{\circ}$ to $8.3^{\circ}$ Brix, highlighting fruits of Okinawa cultivar with higher values. Researches with different acerola cultivars, from the Northeast region of Brazil, showed levels from $6.3^{\circ}$ to $11.4^{\circ} \mathrm{Brix}$ (MACIEL et al., 2010) and $5.8^{\circ}$ to $7.3^{\circ}$ Brix (MUSSER et al., 2004). In Rio de Janeiro state Vendramini and Trugo (2000) has found higher values in ripe fruit $(9.2$ ${ }^{\circ}$ Brix). However, Nasser and Zonta (2014), in São Paulo state, reported values from $6.2^{\circ}$ to $8.1^{\circ} \mathrm{Brix}$ for acerola fruit, similar results found in this study to be collected in the same area of research.

The $\mathrm{pH}$ has shown little variation between cultivars, BRS 237 - Roxinha and BRS 236 - Cereja were more acids (2.85 to 3.0 ) when compared to the other cultivars. The titratable acidity was higher in Okinawa and BRS 236 - Cereja (1.51 and 1.56 $\mathrm{g}$ of malic acid $100 \mathrm{~g}^{-1}$ of pulp, respectively) not differentiating statistically from BRS 235 - Apodi (1.11 $\mathrm{g}$ of malic acid $100 \mathrm{~g}^{-1}$ of pulp). The other cultivars showed lower values, ranging from 0.85 to $1.18 \mathrm{~g}$ of malic acid $100 \mathrm{~g}^{-1}$ of pulp. Acidity levels have been mentioned among different genotypes 
ranging from 0.96 to $1.97 \mathrm{~g}$ of malic acid $100 \mathrm{~g}^{-1}$ of pulp and pH from 2.9 to 3.5 (MACIEL et al., 2010) while Musser et al. (2004) reported values ranging from 0.8 to $1.6 \mathrm{~g}$ of malic acid $100 \mathrm{~g}^{-1}$ of pulp and
3.2 to 3.4 for titratable acidity and $\mathrm{pH}$ respectively. This difference, according to Gomes et al. (2000) may be explained as genotype and environment factors.

Table 1. Soluble solids content (SS - ${ }^{\circ}$ Brix), $\mathrm{pH}$, titratable acidity (TA - g of malic acid $100 \mathrm{~g}^{-1}$ of pulp) and reducing sugar (RS - \% of glucose) in acerola fruits cultivars. Adamantina, 2015.

\begin{tabular}{llllc}
\hline \multicolumn{1}{c}{ Cultivars } & SS & pH & TA & RS \\
\hline BRS 235 - Apodi & $6.76 \mathrm{c}$ & $3.39 \mathrm{a}$ & $1.16 \mathrm{ab}$ & $3.06 \mathrm{c}$ \\
Mirandópolis & $6.96 \mathrm{bc}$ & $3.30 \mathrm{ab}$ & $1.20 \mathrm{~b}$ & $3.20 \mathrm{c}$ \\
Waldy - CATI 30 & $6.66 \mathrm{c}$ & $3.43 \mathrm{a}$ & $1.01 \mathrm{~cd}$ & $3.33 \mathrm{c}$ \\
BRS 238 - Frutacor & $7.46 \mathrm{~b}$ & $3.13 \mathrm{bc}$ & $1.37 \mathrm{~b}$ & $3.39 \mathrm{bc}$ \\
Okinawa & $8.36 \mathrm{a}$ & $3.35 \mathrm{ab}$ & $1.59 \mathrm{a}$ & $4.13 \mathrm{ab}$ \\
BRS 236 - Cereja & $7.10 \mathrm{bc}$ & $3.00 \mathrm{~cd}$ & $1.64 \mathrm{a}$ & $2.89 \mathrm{c}$ \\
Olivier & $7.40 \mathrm{~b}$ & $3.44 \mathrm{a}$ & $0.88 \mathrm{~d}$ & $4.24 \mathrm{a}$ \\
BRS 237 - Roxinha & $7.06 \mathrm{bc}$ & $2.85 \mathrm{~d}$ & $1.22 \mathrm{bc}$ & $3.27 \mathrm{c}$ \\
\hline C.V. (\%) & 3.0 & 2.6 & 5.4 & 8.0 \\
\hline
\end{tabular}

Means followed by the same letter in the column do not differ by Tukey test at $5 \%$ significance level.

It is noteworthy that all cultivars are in accordance with the rules of fruit quality pulp determined by MAPA (Ministério da Agricultura Pecuária e Abastecimento), which requires at least $5.5^{\circ}$ Brix of soluble solids and $\mathrm{pH} 2.8$ (BRASIL, 2000).

The reducing sugar content was higher in fruits of Olivier and Okinawa cultivars (4.24 and 4.13\%, respectively) differing statistically from the other cultivars (ranging from $3.06 \%$ to $3.39 \%$ ). These observed differences among cultivars are probably due to genetic characteristics whereas fruits were harvested with the same ripeness degree, water regime and season. Caetano et al. (2012) cited higher content of reducing sugar $(5.2 \pm 0.2)$ in
Olivier cultivar. França and Narain (2003) have found similar values to the current work (3.5 to $4.0 \%$ ) and as Vendramini and Trugo (2000) reported $4.4 \%$ for reducing sugar in ripe fruit (red).

The peel and pulp colours of acerola cultivars are shown in Table 2. In relation to peel brightness index, cultivars BRS 238 - Frutacor and BRS 236 - Cereja have showed the highest values (30.1 to 31.8, respectively), not differing from BRS 235 Apodi, Mirandópolis, Waldy - CATI 30 and Olivier (26.4, 26.0, 27.2 and 26.1, respectively). In pulp, the highest rate was observed in BRS - Cereja (55.5) and the lowest in Olivier (37.5) and BRS 237 - Roxinha (41.1). 
Table 2. Peel and pulp colour (Luminosity - L, Chroma and ${ }^{\circ} H u e$ ), in acerola fruits cultivars. Adamantina, 2015.

\begin{tabular}{lcccccc}
\hline \multirow{2}{*}{ Cultivars } & \multicolumn{3}{c}{ Peel } & \multicolumn{3}{c}{ Pulp } \\
\cline { 2 - 7 } & L & Chroma & ${ }^{\circ}$ Hue & L & Chroma & ${ }^{\circ}$ Hue \\
\hline BRS 235 -Apodi & $26.4 \mathrm{ab}$ & $26.9 \mathrm{abc}$ & $16.0 \mathrm{ab}$ & $50.8 \mathrm{ab}$ & $40.0 \mathrm{~cd}$ & $63.2 \mathrm{ab}$ \\
Mirandópolis & $26.0 \mathrm{ab}$ & $27.4 \mathrm{abc}$ & $16.2 \mathrm{ab}$ & $53.9 \mathrm{ab}$ & $42.2 \mathrm{abc}$ & $68.7 \mathrm{ab}$ \\
Waldy - CATI 30 & $27.2 \mathrm{ab}$ & $26.6 \mathrm{abc}$ & $18.8 \mathrm{ab}$ & $56.8 \mathrm{a}$ & $43.0 \mathrm{bcd}$ & $76.1 \mathrm{a}$ \\
BRS 238 - Frutacor & $31.8 \mathrm{a}$ & $32.5 \mathrm{ab}$ & $26.1 \mathrm{a}$ & $54.8 \mathrm{ab}$ & $53.5 \mathrm{ab}$ & $68.4 \mathrm{ab}$ \\
Okinawa & $23.8 \mathrm{~b}$ & $23.1 \mathrm{bc}$ & $13.1 \mathrm{~b}$ & $49.4 \mathrm{abc}$ & $44.2 \mathrm{abcd}$ & $67.2 \mathrm{ab}$ \\
BRS 236 - Cereja & $30.1 \mathrm{a}$ & $33.7 \mathrm{a}$ & $19.6 \mathrm{ab}$ & $55.5 \mathrm{ab}$ & $55.2 \mathrm{a}$ & $69.4 \mathrm{ab}$ \\
Olivier & $26.1 \mathrm{ab}$ & $24.3 \mathrm{abc}$ & $17.9 \mathrm{ab}$ & $41.1 \mathrm{c}$ & $35.3 \mathrm{~d}$ & $53.3 \mathrm{bc}$ \\
BRS 237 - Roxinha & $23.3 \mathrm{~b}$ & $19.45 \mathrm{c}$ & $17.5 \mathrm{ab}$ & $37.5 \mathrm{c}$ & $41.2 \mathrm{~cd}$ & $41.6 \mathrm{c}$ \\
\hline C.V. (\%) & 7.9 & 13.8 & 19.9 & 10.9 & 9.1 & 11.8 \\
\hline
\end{tabular}

Means followed by the same letter in the column do not differ by Tukey test at 5\% significance level.

For the angle Hue, which indicates the tonality of the fruit peel, it is observed that cv. BRS 238Frutacor, Waldy - CATI 30 and BRS 236 - Cherry are red in color, while BRS 235-Apodi, Mirandópolis, Okinawa, Olivier and BRS 237-Roxinha are in the red violet color range. In relation to colour saturation (Chroma) BRS 236 - Cereja presented the highest values (33.7) while BRS 237 - Roxinha the lowest one (19.4). Similar red range colour as reported in the current work was observed by Adriano et al. (2011) in cultivar Olivier. Figueiredo Neto et al. (2014), working with Okinawa cited colour red peel in ripe fruit $\left({ }^{\circ} \mathrm{Hue}\right.$ : 23.4) and higher saturation into the survey data.

The pulp presented red tonality for the cv. BRS 237 - Roxinha and BRS 238 - Frutacor and orange pulp for cultivars BRS 235 - Apodi, Mirandópolis, Waldy - CATI 30, Okinawa and BRS 236 Cherry. For color saturation, the highest indices were observed in fruits of cv. BRS 236- Cherry and smaller to cv. Olivier. These results are in accordance with Standards of Identity and Quality for fruit juices, which require red-yellow colour to pulp (BRASIL, 2003).

Among cultivars significant differences were observed in relation to ascorbic acid contents (Table 3) ranging from 824.6 to $2,331.6 \mathrm{mg}$ of ascorbic acid $100 \mathrm{~g}^{-1}$ of pulp. The highest level was observed in BRS 236 - Cereja fruits, differing significantly from the other cultivars, and presenting content around $64 \%$ higher than cv. Olivier. 
Table 3. Ascorbic acid content (mg of ascorbic acid $100 \mathrm{~g}^{-1}$ of pulp), total antioxidant activity (\%), total phenolics compounds (mg of gallic acid $100 \mathrm{~g}^{-1}$ of pulp) and flavonoids (mg of quercetin $100 \mathrm{~g}^{-1}$ of pulp). Adamantina, 2015.

\begin{tabular}{lcccc}
\hline \multicolumn{1}{c}{ Cultivars } & Ascorbic acid & $\begin{array}{c}\text { Total antioxidant } \\
\text { activity }\end{array}$ & $\begin{array}{c}\text { Total phenolics } \\
\text { compounds }\end{array}$ & $\begin{array}{c}\text { Flavonoids } \\
\text { (quercetin) }\end{array}$ \\
\hline BRS 235 -Apodi & $1,479.0 \mathrm{~d}$ & $90.3 \mathrm{ab}$ & $914.2 \mathrm{~d}$ & $8.17 \mathrm{ab}$ \\
Mirandópolis & $1,594.8 \mathrm{~d}$ & $90.3 \mathrm{ab}$ & $1489.3 \mathrm{bcd}$ & $7.99 \mathrm{ab}$ \\
Waldy - CATI 30 & $1,835.4 \mathrm{c}$ & $89.9 \mathrm{ab}$ & $1437.9 \mathrm{bcd}$ & $12.34 \mathrm{a}$ \\
BRS 238 - Frutacor & $1,478.4 \mathrm{~d}$ & $89.8 \mathrm{ab}$ & $1028.1 \mathrm{~cd}$ & $8.43 \mathrm{ab}$ \\
Okinawa & $2,102.0 \mathrm{~b}$ & $89.9 \mathrm{ab}$ & $1277.8 \mathrm{bcd}$ & $6.61 \mathrm{ab}$ \\
BRS 236 - Cereja & $2,331.6 \mathrm{a}$ & $90.7 \mathrm{a}$ & $2428.3 \mathrm{a}$ & $3.56 \mathrm{~b}$ \\
Olivier & $824.6 \mathrm{f}$ & $90.5 \mathrm{a}$ & $1738.9 \mathrm{~b}$ & $12.29 \mathrm{a}$ \\
BRS 237 - Roxinha & $1,241.5 \mathrm{e}$ & $88.0 \mathrm{~b}$ & $1668.3 \mathrm{bc}$ & $9.19 \mathrm{ab}$ \\
\hline C.V. (\%) & 4.3 & 0.9 & 16.0 & 33.0 \\
\hline
\end{tabular}

Means followed by the same letter in the column do not differ by Tukey test at $5 \%$ significance level.

In mature stage, different acerola genotypes are reported in the literature with contents from 835.0 a $1,820.0$ (MATSUURA et al., 2001); 940.0 to $2,000.0$ (FRANÇA; NARAIN, 2003); 1,340.0 \pm 9.0 (RUFINO et al., 2009); 750.0 to $1,648.0 \mathrm{mg}$ of ascorbic acid $100 \mathrm{~g}^{-1}$ of pulp (MACIEL et al., 2010); $1,457.69 \pm 279.92$ (FREIRE et al., 2013).

Similar to current work Adriano et al. (2011) reported levels of $810.2 \pm 53.3 \mathrm{mg}$ of ascorbic acid $100 \mathrm{~g}^{-1}$ of pulp in Olivier ripe fruit. Higher levels, $3,629.6 \mathrm{mg}$ of ascorbic acid $100 \mathrm{~g}^{-1}$ of pulp were found by Figueiredo Neto et al. (2014), in mature fruits of Okinawa. Ascorbic acid levels vary considerably according to degree of maturation, conditions of cultivation, storage and processing (CHITARRA; CHITARRA, 2005). However, it is important to highlight all cultivars exceed the recommended $\mathrm{C}$ vitamin intake showing that they are excellent sources for human diet. The consumption of approximately $10 \mathrm{~g}$ of any cultivars has already reached the daily recommendation of $\mathrm{C}$ vitamin.

The highest total antioxidant activity was observed in BRS 236 - Cereja (90.7\%) and Olivier (90.5\%) not differing statistically from BRS 235 -
Apodi, Mirandópolis, Waldy - CATI 30, BRS 238 - Frutacor and Okinawa. BRS 237- Roxinha fruits had the lowest activity (88\%) when compared to BRS 236 - Cereja and Olivier (Table 3).

Melo et al. (2008) also find high values of total antioxidant activity, furthermore, authors cited acerola fruit presented larger activity comparing to pineapple, mango, melon, pine and watermelon due to its higher efficiency in sequestering the free radical (>90\%). Paz et al. (2015) observed higher value in acerola when compared to assai and yellow mombim. Rufino et al (2010) using methanolic extract, observed that acerola has lower antioxidant activity in relation to yellow mombim, cashew apple and assai. Lima et al. (2011), researching antioxidant activity in 11 acerola genotypes found percentage from $36.97 \%$ to $63.92 \%$ and from 73.27 to $94.54 \%$ among genotypes. Sagar et al. (2014) found lower values than the current study, $89.1 \%$ of antioxidant activity in fruits of mature acerola (red colour) produced in India.

Phenolic compounds in acerola fruits ranged from 914.2 to $2,428.3 \mathrm{mg}$ of gallic acid $100 \mathrm{~g}^{-1}$ of pulp. The highest levels were observed in fruits of BRS 236 - Cereja and lowest levels in BRS 235 
- Apodi (Table 3). According to Menichini et al. (2009), genotype is one of the factors that influences the amount of phytochemicals in plant material. Researches developed using Folin-Ciocalteu reactive to determine levels of phenolic compounds reported that Melo et al. (2008) found values of $4,962.0 \pm 65.57 \mathrm{mg}$ of gallic acid $100 \mathrm{~g}^{-1}$ of pulp; Rufino et al. (2009) cited values of $1,063.3 \pm 53$, Freire et al. (2013) found 1,489.0 \pm 100.01 and Paz et al. (2015) reported $12466 \mathrm{mg}$ of gallic acid $100 \mathrm{~g}^{-1}$ on a dry weight basis. Phenolic compounds collaborate to fruit colour and flavour quality, contributing to the astringency and bitterness (VENDRAMINI; TRUGO, 2004). Sagar et al. (2014) concluded that acerola is a fruit with high antioxidant activity, and phenolic compounds are the main components of this activity.

Flavonoids average values ranged from 3.56 to $12.34 \mathrm{mg}$ of quercetin $100 \mathrm{~g}^{-1}$ of pulp (Table 3), similar result reported by Maciel et al. (2010) which presented 4.40 to $13.21 \mathrm{mg}$ of quercetin $100 \mathrm{~g}^{-1}$ of pulp. Two most planted cultivars in São Paulo state, Olivier and Waldy - CATI 30 showed higher values than BRS 236 - Cereja on flavonoids, which shows the difference of this compound according to planted cultivars. Vendramini and Trugo (2004) reported value of $8.82 \mathrm{mg}$ of quercetin $100 \mathrm{~g}^{-1}$ of pulp for Okinawa. In the other hand, Mazaro et al. (2015) working with salicylic acid application in organic acerola fruit in Parana state, showed levels from 1 to $5 \mathrm{mg}$ of quercetin $100 \mathrm{~g}^{-1}$ of pulp. Paz et al. (2015) evaluating flavonoids in different tropical fruits, observed that acerola presented values superior to mango and pineapple.

\section{Conclusions}

Analysed acerola cultivars showed being good sources of phenolic compounds and antioxidant activity, ensuring theis excellent nutritional quality relative to free radicals combat.

BRS 236 - Cereja cultivar presented the highest levels of ascorbic acid content, antioxidant activity, phenolic compounds and the lowest flavonoids values, which was higher than the other cultivars, especially Olivier and Waldy CATI-30.

\section{Acknowledgement}

To experimental station of Polo Regional Alta Paulista of Agência Paulista em Tecnologia dos Agronegócios (APTA) located at municipality of Adamantina-SP, Brazil for fruit donation to work execution.

\section{References}

ADRIANO, E.; LEONEL, S.; EVANGELISTA, R. M. Qualidade de fruto da aceroleira cv. Olivier em dois estádios de maturação. Revista Brasileira de Fruticultura, Jaboticabal, v. 33, n. 1, p. 541-545, 2011.

AGOSTINI-COSTA, T. da S.; ABREU, L. N. de; ROSSETTI, A. G. Efeito do congelamento e do tempo de estocagem da polpa de acerola sobre o teor de carotenóides. Revista Brasileira de Fruticultura, Jaboticabal, v. 25, n. 1, p. 56-58, 2003.

AMAYA-FARFAN, J.; DOMENE, S. M.A.; PADOVANI, R. M. DRI: Síntese comentada das novas propostas sobre recomendações nutricionais para antioxidantes. Revista de Nutrição, Campinas, v. 14, n.1, p. 71-78, 2001.

ANDRADE, J.; CARDOSO, M. G.; SOUSA, P. E.; TEIXEIRA, M. L.; GOMES, M. S.; SILVA, L. F.; MIRANDA, C. A. S. F. Quantificação fenólica, atividade antifúngica e antioxidante de extratos provenientes da aceroleira (Malpighia emarginata DC.). Magistra, Cruz das Almas, v. 25, n. 3-4, p. 276-284. 2013.

AWAD, A. M.; JAGER, A.; WESTING, L. M. Flavonoid and chlorogenic acid levels in apple fruit: characterization of variation. Scientia Horticulturae, Mission, v. 83, n. 3, p. 249-263, 2000.

BRASIL. Instrução normativa n 12, de 4 de setembro de 2003. Regulamento técnico para fixação dos padrões de identidade e qualidade gerais para suco tropical. Diário Oficial [da] União, Brasília, DF, 9 set. 2003. Seção 1, p. 3.

Ministério da Agricultura Pecuária e Abastecimento. Instrução normativa n. 1 de 07 de janeiro de 2000. Padrão de identidade e qualidade para polpas de frutas. Diário Oficial [da] União, Brasília, DF, 10 jan. 2000. Seção 1, p. 54. 
Instrução Normativa n. 24 de 08 de setembro de 2005. Estabelece o Manual de métodos de análises de bebidas e vinagres do MAPA. Diário Oficial [da] União, Brasília, DF, 20 set. 2005. Seção 1, p. 11. Disponível em: <http//www.agricultura.gov.br/ legislação-Sislegis>. Acesso em: 01 ago. 2016.

CAETANO, P. K.; DAIUTO, E. R.; VIEITES, R. L. Característica físico-química e sensorial de geleia elaborada com polpa e suco de acerola. Brazilian Journal Food Technology, Campinas, v. 15, n. 3, p. 191-197, 2012.

CHITARRA, M. I. F.; CHITARRA, A. B. Pós-colheita de frutas e hortaliças: fisiologia e manuseio. Lavras: UFLA, 2005. $783 \mathrm{p}$.

DE ROSSO, V. V.; MERCADANTE, A. Z. Carotenoid composition of two Brazilian genotypes of acerola (Malpighia punicifolia L.) from two harvests. Food Research International, Toronto, v. 38, n. 8-9, p. 10731077, 2005.

\section{EMPRESA BRASILEIRA DE PESQUISA} AGROPECUÁRIA - EMBRAPA. Centro Nacional de Pesquisa de Solo. Sistema brasileiro de classificação de solos. 2. ed. Rio de Janeiro, 2006. 306 p.

FIGUEIREDO NETO, A.; REIS, D. S.; ALVES, E.; GONÇALVES, E.; ANJOS, F. C.; FERREIRA, M. Determinação de vitamina c e avaliação físico-química em três variedades de acerola cultivadas em PetrolinaPE. Nucleus, Ituverava, v. 11, n. 1, p. 83-92, 2014.

FRANÇA, V. C.; NARAIN, N. Caracterização química dos frutos de três matrizes de acerola (Malpighia emarginata D.C.). Ciência e Tecnologia de Alimentos, Campinas, v. 23, n. 2, p. 157-160, 2003.

FREIRE, J. M.; ABREU, C. M. P.; ROCHA, D. A.; CORRÊA, A. D.; MARQUES, N. C. Quantificação de compostos fenólicos e ácido ascórbico em frutos e polpas congeladas de acerola, caju, goiaba e morango. Ciência Rural, Santa Maria, v. 43, n. 12, p. 2291-2295, 2013.

FURLANETO, F. P. B.; NASSER, M. D. Panorama da cultura da acerola no Estado de São Paulo. Pesquisa \& Tecnologia, Campinas, v. 12, n. 1, 2015. Disponível em: $<$ http://www.aptaregional.sp.gov.br/acesse-os-artigospesquisa-e-tecnologia/edicao-2015/janeiro-junho3/1637-panorama-da-cultura-da-acerola-no-estado-desao-paulo/file.html?force_download=1>. Acesso em: 30 jul. 2015.

GOMES, J. E.; PERECIN, D.; MARTINS, A. B. G.; ALMEIDA, E. J. Variabilidade fenotípica em genótipos de acerola. Pesquisa Agropecuária Brasileira, Brasília, v. 35 , n. 11 , p. 2205-2211, 2000.
HERRERA, O. M.; LEOPOLDO, P. R.; KROLL, L. B.; ZUCCARI, M. L. Agrupamento de estações climatológicas localizadas no Estado de São Paulo, utilizando-se análise multivariada. Engenharia Agrícola, Jaboticabal, v. 16, n. 3, p. 34-42, 1997.

INSTITUTO ADOLFO LUTZ. - IAL. Normas analíticas do Instituto Adolfo Lutz. I - métodos químicos e físicos para análise de alimentos. 3. ed. São Paulo: IAL, 1985. $533 \mathrm{p}$.

LEE, S. K.; KADER, A. A. Preharvest and postharvest factors influencing vitamin $\mathrm{C}$ content of horticultural crops. Postharvest Biology and Technology, Amsterdam, v. 20, n. 3, p. 207-220, 2000.

LIMA, V. L. A. G.; MÉLO, E. A; PINHEIRO, I. O.; GUERRA, N. B. Antioxidant capacity of anthocyanins from acerola genotypes. Ciência e Tecnologia de Alimentos, Campinas, v. 31, n. 1, p. 86-92, 2011.

MACIEL, M. I. S., MELO, E.; LIMA, V. SOUZA, K. A.; SILVA, W. Caracterização físico-química de frutos de genótipos de aceroleira (Malpighia emarginata D.C.). Ciência Tecnologia de Alimentos, Campinas, v. 30, n.4, p. 865-869, 2010.

MATSUURA, F. C. A. U.; CARDOSO, R. L.; FOLEGATTI, M. I. S.; OLIVEIRA, J. R.; OLIVEIRA, J. A. B.; SANTOS, D. B. Avaliações físico-químicas em frutos de diferentes genótipos de acerola (Malpighia punicifolia L.). Revista Brasileira Fruticultura, Jaboticabal, v. 23, n. 3, p. 602-606, 2001.

MAZARO, S. M.; BORSATTI, F. C.; DALACOSTA, N. L.; LEWANDOWSKI, A.; DANNER, M. A.; BUSSO, C.; WAGNER JÚNIOR, A. Qualidade pós-colheita de acerolas tratadas com ácido salicílico. Agrária, Recife, v. 10, n. 4, p. 512-517, 2015.

MELO, E. A.; MACIEL, M. I. S.; LIMA, V. L. A. G., NASCIMENTO, R. J. Capacidade antioxidante de frutas. Revista Brasileira de Ciências Farmacêuticas, São Paulo, v. 44, n. 2, p. 193-201, 2008.

MENICHINI, F.; TUNDIS, R.; BONESI, M.; LOIZZO, M. R.; CONFORTI, F.; STATTI, G.; De CINDIO, B.; HOUGHTON, P. J.; MENICHINI, F. The influence of fruit ripening on the phytochemical content and biological activity of Capsicum chinense Jacq. cv Habanero. Food Chemistry, London, v. 114, n. 2, p. 553-560, 2009.

MENSOR, L. L.; MENEZES, F. S.; LEITÃO, G. G.; REIS, A. S.; SANTOS, T. C.; CINTIA, S.; COUBE, C. S.; LEITÃO, S. G. Screening of brazilian plant extracts for antioxidant activity by the use of dpph free radical method. Phytotherapy Research, Massachusetts, v. 15, n. 2, p. 127-130, 2001. 
MERCALI, G. D.; JAESCHKE, D. P.; TESSARO, I. C.; MARCZAK, L. D. F. Degradation kinetics of anthocyanins in acerola pulp: Comparison between ohmic and conventional heat treatment. Food Chemistry, Barking, v. 136, n. 2, p. 853-857, 2013.

MINOLTA, K. Comunicação precisa da cor: controle de qualidade da percepção à instrumentação. Osaka: Konika Minolta Sensing, INC, 1998. 59 p.

MUSSER, R. S.; LEMOS, M. A.; LIMA, V. L. A. G.; MÉLO, E. A.; LEDERMAN, I. E.; SANTOS, V. F. Características físico-químicas de acerola do banco ativo de germoplasma em Pernambuco. Ciência e Tecnologia de Alimentos, Campinas, v. 24, n. 4, p. 556-561, 2004.

NASSER, M. D.; ZONTA, A. Caracterização de frutos de genótipos de aceroleira em função de estádios de maturação. Tecnologia \& Ciência Agropecuária, João Pessoa, v. 8, n. 5, p. 76-78, 2014.

NELSON, N. A. A photometric adaptation of Somogy method for the determination of Glucose. Journal Biological Chemistry, Bethesda, v. 153, p. 375-380, 1944.

PAZ, M.; GÚLLON, P.; BARROSO, M. F.; CARVALHO, A. P.; DOMINGUES, V. F.; GOMES, A. M.; BECKER, H.; LONGHINOTTI, E.; DELERUE-MATOS, C. Brazilian fruits pulps as functional foods and additives: Evaluation of bioactive compounds. Food Chemistry, Amsterdam, v. 172, p. 462-468, 2015.

RITZINGER, R., RITZINGER, C. H. S. P. Acerola. Informe Agropecuário, Belo Horizonte, v. 32, n. 264, p. 17-25, 2011.

ROCHA, M. S.; FIGUEIREDO, R. W. de; ARAUJO, M. A. da M.; MOREIRA-ARAUJO, R. S. dos R. Caracterização físico-química e atividade antioxidante (in vitro) de frutos do cerrado Piauiense. Revista Brasileira de Fruticultura, Jaboticabal, v. 35, n. 4, p. 933-941, 2013.
RUFINO, M. S. M.;ALVES, R. E.;ALVES, R. E.; BRITO, E. S.; PÉREZ-JIMÉNEZ, J.; SAURA-CALIXTO, F.; MANCINI-FILHO, J. Bioactive compounds and antioxidant capacities of 18 non-tradiotional tropical fruits from Brazil. Food Chemistry, Amsterdam, v. 121, n. 4, p. 996-1002, 2010.

RUFINO, M. S. M.; FERNANDES, F. A. N.; ALVES, R. E.; BRITO, E. S. Free radical-scavenging behaviour of some north-east Brazilian fruits in a DPPH system. Food Chemistry, Barking, v. 114, n. 2, p. 693-695, 2009.

SAGAR, S. B.; KAVITHA, C.; KUNA, A. Antioxidant Properties of Acerola (Malpighia Emarginata Dc.) and Acerola squash. International Journal of Science and Research, Raipur, v. 3, n. 7, p. 2176-2179, 2014.

SANTOS, M. D.; BLATT, C. T. T. Teor de flavonoides e fenóis totais em folhas de Pyrostegia venusta Miers de mata e de cerrado. Revista Brasileira de Botânica, São Paulo, v. 21, n. 2, p. 135-140, 1998.

SINGLETON, V. L.; ORTHOFER, R.; LAMUELARAVENTÓS, R. M. Analysis of total phenols and other oxidation substrates and antioxidants by means of FolinCiocalteau reagent. Methods in Enzymology, New York, v. 299, n. 1, p. 152-178, 1999.

SOMOGY, M. Determination of blooded sugar. Journal Biologic Chemical, Baltimore, n. 160, p. 69-73, 1945.

VENDRAMINI, A. L.; TRUGO, L. C. Chemical composition of acerola fruit (Malpighia punicifolia L.) at three stages of maturity. Food Chemistry, Toronto, v. 71, n. 2 , p. $195-198,2000$.

Phenolic compounds in acerola fruit (Malpighia punicifolia L.). Journal of the Brazilian Chemical Society, São Paulo, v. 15, n. 5, p. 664-668, 2004.

VIEIRA, L. M.; SOUSA, M. S. B.; MANCINI-FILHO, J.; LIMA, A. Fenólicos totais e capacidade antioxidante in vitro de polpas de frutos tropicais. Revista Brasileira de Fruticultura, Jaboticabal, v. 33, n. 3, p. 888-897, 2011. 